\title{
External ophthalmomyiasis: case reports of two cases associated with agrarian practices
}

\begin{abstract}
The most common cause of ophthalmomyiasis worldwide is Oestrusovis (Sheep botfly) larvae. Infestation by Oestrus ovis commonly cause external ophthalmomyiasis (EOM), but there is also a risk of internal ophthalmomyiasis, in which larvae may penetrate the ocular globe. The condition commonly presents as foreign body sensation, watering \& redness of the eye. The condition is often misdiagnosed as an acute conjunctivitis. We describe here two cases of ophthalmomyiasis, who presented with symptoms of foreign body sensation, lacrimation, pain and redness the eye. The larvae were observed in the conjunctival sac. Following their removal, the symptom of eye inflammation improved in a few hours. Both the cases reported here were linked to agrarian practices (husking paddy \& tilling of soil) \& the patients were farmers from rural areas. This underscores the importance of incorporating the preventive awareness programme of External/Internal ophthalmomyiasis for our farmers.
\end{abstract}

Keywords: ophthalmomyiasis, oestrus ovis, agrarian practices

\author{
Volume 5 Issue 4 - 2017
}

\author{
Manodeep Sen,' Anupam Das, ${ }^{2}$ Meenakshi \\ Sharma, ${ }^{3}$ Vineeta Mittal, ${ }^{4}$ Rahul singh ${ }^{5}$ \\ 'Department of Microbiology, Dr. Ram Manohar Lohia Institute \\ of Medical Sciences, India \\ ${ }^{2}$ Department of Ophthalmology, Dr. Ram Manohar Lohia \\ Combined Hospital, India
}

Correspondence: Meenakshi Sharma, Senior Resident, Department of Microbiology, Dr. Ram Manohar Lohia Institute of Medical Sciences, VibhutiKhand, Gomti Nagar, Lucknow226010, India, Tel +919919224458, Email meenakshi_lhmc@gmail.com

Received: June 18, 2017| Published: November 02, 2017

\section{Introduction}

Myiasis, the infestation of humans with dipterous fly maggots, is common in the tropical countries with a large fly population. ${ }^{1}$ Ophthalmomyiasis refers to the infestation of the eye and the ocular adnexa by the larval form of dipterous flies. Based on the parts of the eye which are involved, there are three types of Ophthalmomyiasis. The first type is the Ophthalmomyiasis externa in which only conjunctiva is involved. This condition, if it is not managed in time, can lead to two other of its dreaded types, such as Ophthalmomyiasis interna (the larvae invades the ocular globe and they are found in the sub-retinal space and the vitreous cavity) and orbital Ophthalmomyiasis (invasion of the orbit). ${ }^{2,3}$ Ocular involvement or ophthalmomyiasis is seen to occur in about $5 \%$ of all cases of myiasis. ${ }^{2}$ Larvae, most commonly, attack the external surface of the eyes or ocular adnexea, e.g. the lids, conjunctiva or lacrimal ducts (external ophthalmomyiasis, EOM). Ophthalmomyiasis externa is mainly caused by sheep bot fly (Oestrus ovis). Therefore, this is more common in the farming communities. ${ }^{3}$ Very few cases of Ophthalmomyiasis externa which were caused by Oestrus ovis infestation have been reported so far from India.

\section{Case I}

A fifty two years old female presented to the ophthalmic OPD of Dr. Ram Manohar Lohia Combined Hospital with complaints of mild pain \& ocular discomfort and watering of right eye for one day. She was apparently well a day before when something fell into her eye while she was husking rice. After that she complained of irritation, watering and pain from the affected eye. No other significant medical history was given. An ophthalmic examination revealed a visual acuity of $6 / 9$ in both the eyes. Rest of the ocular examination was within normal limits. The conjunctiva was mildly congested, with profuse lacrimation in the affected eye.

On slit lamp examination, approximately $1-2 \mathrm{~mm}$ long translucent multiple organisms with black heads were seen, moving over the conjunctiva in the affected eye. The wormlike organisms were present in bulbar and forniceal conjunctiva. About 5-6 maggots were removed from the conjunctiva under topical anaesthesia.

On macroscopic examination, the worms were milky white maggots of about $2 \mathrm{~mm}$ in size. Microscopy revealed spindle shaped skeleton with multiple segments. A pair of sharp, dark brown oral hooks was attached to the internal cephalopharyngeal skeleton and tufts of numerous brown hooks were on the margins of each body segment. They were identified as the first stage larvae of O. ovis, the sheep nasal bot fly.

The patient was given topical anti inflammatory and antibiotic drops. When the patient returned for follow up after five days, she was completely relieved of her symptoms of foreign body sensation and lacrimation. A repeat slit lamp examination was normal.

\section{Case 2}

A seventy five years old male presented to the ophthalmic OPD of Dr. Ram Manohar Lohia Combined Hospital with complaints of mild pain, redness and watering of both the eyes for one day. He was hit in both of his eyes with soil particles, while digging in a field. On ocular examination he had visual acuity of 6/60 in his right eye \& 6/12 in left eye. The conjunctiva of both the eyes were mildly congested with profuse lacrimation. He had cataract in his right eye \& Intra Ocular Lens was implanted in left eye.

On slit lamp examination, approximately $1-2 \mathrm{~mm}$ long translucent multiple organisms with black heads were seen, moving over the conjunctiva in both the eyes. The worm like organisms were present in conjunctival sac of both the eyes. About 10-12 maggots were removed from the right eye \& 1-2 from the left eye, under topical anaesthesia under slit lamp examination.

On macroscopic examination, the worms were milky white maggots of about $2 \mathrm{~mm}$ in size. Microscopy revealed spindle shaped skeleton with multiple segments. A pair of sharp, dark brown oral hooks was attached to the internal cephalopharyngeal skeleton and tufts of numerous brown hooks were on the margins of each body segment. They were identified as the first stage larvae of O. ovis, the sheep nasal bot fly. 
The patient was given a combination of topical anti inflammatory and antibiotic drops as in the first case. When the patient returned for follow up in the next week, he was completely relieved of the symptoms .Slit lamp examination was performed and no maggots were seen.

\section{Discussion}

Ophthalmic myiasis is caused by the deposition of fly larvae in the human eyes. Various species of flies are able to provoke ophthalmomyiasis, which include Oestrus ovis, latrine fly (Fannia), house fly (Muscadomestica) and cattle botfly (Hypoderma). ${ }^{4,5}$ Oestrus ovisis by far, the most common cause of ophthalmic myiasis in man. ${ }^{6}$ Sheep bot fly (Oestrus ovis) is a cosmopolitan parasite of sheep and goats. It is important to identify the species as some of these are ectoparasites are prone to cause complications like ocular globe penetration. Therefore prompt diagnosis and management is mandatory to prevent blindness.

The ophthalmic myiasis in human beings, which is caused by Oestrus ovis, was described for the first time in 1947 by James. ${ }^{7}$ More scattered cases were reported since then from the Mediterranean area, like Italy, and also from Russia, Serbia (previous Yugoslavia), Africa, America, and Oman (Figure 1). ${ }^{8,9}$ Many cases have been reported recently from various parts of India. Myiasis is more common than what has been indicated by the previously published reports. ${ }^{10,11} \mathrm{We}$ attempted a review of few case reports of Ophthalmomyiasis externa from various parts of India (Table 1). Human myiasis mostly occurs in the rural areas, where man lives in close contact with small ruminants.

Table I Clinical and biochemical variables of individuals with overweight-obesity

\begin{tabular}{|c|c|c|c|c|c|}
\hline S. no & Study and references & Age (Year) & Mode of injury & Causative species & Outcome \\
\hline I & $\begin{array}{l}\text { Nandita Pal. } 2016 \text { Kolkata } \\
\text { (case report) }\end{array}$ & 36 & $\begin{array}{l}\text { Dust entering the eye while boarding a roadside } \\
\text { cab. }\end{array}$ & $\begin{array}{l}\text { First instar larvae of } \\
\text { O. ovis }\end{array}$ & $\begin{array}{l}\text { Completely } \\
\text { relieved of } \\
\text { symptoms }\end{array}$ \\
\hline 2 & $\begin{array}{l}\text { K.Mohan Raj et al. } 2015 . \\
\text { Chennai (Case report) }\end{array}$ & 23 & $\begin{array}{l}\text { Exposure to dust which fell into his eye while } \\
\text { walking on the road close to a sugarcane juice } \\
\text { vendor's shop }\end{array}$ & $\begin{array}{l}\text { Drosophila } \\
\text { Melanogaster. Fruit fly } \\
\text { or vinegar fly }\end{array}$ & $\begin{array}{l}\text { cCmpletely } \\
\text { relieved of } \\
\text { symptoms }\end{array}$ \\
\hline 3 & $\begin{array}{l}\text { P. Maurya et al.20I I Varanasi } \\
\text { (Case report) }\end{array}$ & $\begin{array}{l}\text { I.5 urban } \\
\text { slum }\end{array}$ & Superimposed infection on injured eye & $\begin{array}{l}\text { Flesh Fly, Wohlfahrtia } \\
\text { magnifica }\end{array}$ & $\begin{array}{l}\text { Completely } \\
\text { relieved of } \\
\text { symptoms }\end{array}$ \\
\hline 4 & $\begin{array}{l}\text { PankajChoudhary et al. } 2012 \\
\text { (case series of } 6 \text { cases) Rewa }\end{array}$ & $14-25$ & Not mentioned & Oestrus ovis & $\begin{array}{l}\text { Completely } \\
\text { relieved of } \\
\text { symptoms }\end{array}$ \\
\hline 5 & $\begin{array}{l}\text { Mahesh Kumar Shankar et al. } \\
2012 \text { Hubli (Case report) }\end{array}$ & 50 & Something fell in the eye while working at fields & $\begin{array}{l}\text { First stage larvae of } \\
\text { O. ovis }\end{array}$ & $\begin{array}{l}\text { Completely } \\
\text { relieved of } \\
\text { symptoms }\end{array}$ \\
\hline 6 & $\begin{array}{l}\text { Punit K. Singh et al. } 2012 \\
\text { Jodhpur (case report of } 3 \\
\text { cases) }\end{array}$ & $\begin{array}{ll}\text { i. } & 11 \\
\text { ii. } & 45 \\
\text { iii. } 25\end{array}$ & $\begin{array}{l}\text { i. Playing in felds } \\
\text { ii. Working in felds } \\
\text { iii. Working in felds }\end{array}$ & Oestrus ovis & $\begin{array}{l}\text { Completely } \\
\text { relieved of } \\
\text { symptoms }\end{array}$ \\
\hline 7 & $\begin{array}{l}\text { S Khurana et al. } 2010 \\
\text { Chandigarh (case report) } 3 \\
\text { cases }\end{array}$ & $\begin{array}{l}\text { i. } 80 \\
\text { ii. } 30 \\
\text { iii. } 17\end{array}$ & $\begin{array}{l}\text { i. Case of squamous cell carcinoma of the } \\
\text { eyelid skin } \\
\text { ii. Unknown } \\
\text { iii. insect forcibly striking the eye }\end{array}$ & $\begin{array}{l}\text { i. larva of the fly C. } \\
\text { hominivorax. } \\
\text { ii. Oestrus ovis } \\
\text { iii. Oestrus ovis }\end{array}$ & $\begin{array}{l}\text { i. patient failed to } \\
\text { appear for follow- } \\
\text { up } \\
\text { ii. cases } \\
\text { completely } \\
\text { relieved of } \\
\text { symptoms }\end{array}$ \\
\hline 8 & $\begin{array}{l}\text { Anita Pandey et al. } 2009 . \\
\text { Meerut (Case report) }\end{array}$ & 25 & $\begin{array}{l}\text { Something falling in the eye while resting under } \\
\text { a tree }\end{array}$ & $\begin{array}{l}\text { First stage larvae of } \\
\text { O. ovis }\end{array}$ & $\begin{array}{l}\text { Completely } \\
\text { relieved of } \\
\text { symptoms }\end{array}$ \\
\hline 9 & $\begin{array}{l}\text { Shubhangi Nigwekar, } 2009 \\
\text { Loni,Maharashtra - (Case } \\
\text { report)- }\end{array}$ & 35 & Contact with farm animals & $\begin{array}{l}\text { First stage larvae of } \\
\text { O. ovis }\end{array}$ & $\begin{array}{l}\text { Completely } \\
\text { relieved of } \\
\text { symptoms }\end{array}$ \\
\hline 10 & $\begin{array}{l}\text { Gajiwala Uday R et al. } 2009 \\
\text { Bharuch, Gujarat, (case } \\
\text { report) } 4 \text { cases }\end{array}$ & $\begin{array}{ll}\text { i. } & 25 \\
\text { ii. } & 30 \\
\text { iii. } & 35 \\
\text { iv. } 60\end{array}$ & $\begin{array}{l}\text { i. Working in the field } \\
\text { ii. Working in the field } \\
\text { iii. Traveling on a bike } \\
\text { iv. While Grazing Goats/Sheeps in the field }\end{array}$ & $\begin{array}{l}\text { First stage larvae of } \\
\text { O. ovis }\end{array}$ & $\begin{array}{l}\text { Completely } \\
\text { relieved of } \\
\text { symptoms }\end{array}$ \\
\hline
\end{tabular}

SD, standard deviation; BMI, body mass index;WC, waist circumference; $A C$, abdominal circumference; $H C$, hip circumference; RER, respiratory exchange ratio; HR, hear rate. 


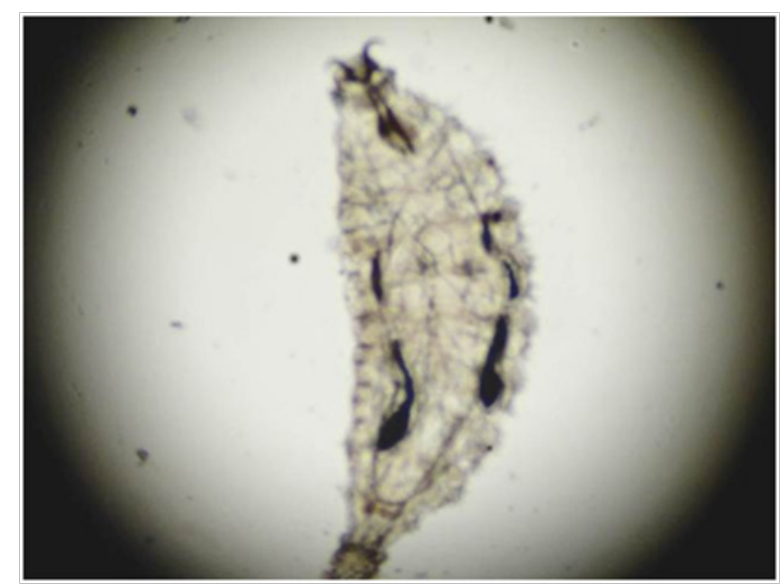

Figure I O. ovis larvae showing segments with intersegmental spine bands (I), tufts of brown hooks on the margins of each body segment (2), oral hooks(3), and oral hooks seen attached to the internal cephalopharyngeal skeleton (4).

\section{Conclusion}

Both the cases reported here were linked to agrarian practices (husking paddy\& tilling of soil) \& the patients were farmers from rural areas. External Ophthalmomyiasis should be considered as an occupational disease among farmers and shepherds. Use of protective eye wear during husking and tilling soil, can prove useful in preventing injuries to eyes from such insects. This underscores the importance of incorporating the preventive awareness programme of External/ Internal ophthalmomyiasis for our farmers.

\section{Acknowledgements}

None.

\section{Conflict of interest}

The author declares no conflict of interest.

\section{References}

1. Gopalakrishnan S, Srinivasan R, Saxena SK, et al. Myiasis in different types of carcinoma cases in southern India. Indian $J$ Med Microbiol. 2008;26(2):189-192.

2. Seema B, Santosh S, Rekha B, et al. Ophthalmomyiasis external: A case report. Journal of Clinical and Diagnostic Research. 2012;6:1079-1080.

3. Sigauke E, Beebe WE, Gander RM, et al. A case report: Ophthalmomyiasis externa in Dallas County, Texas. The Am J Trop med Hyg. 2003;68:4647.

4. Mandell GL, Douglas RG, Bennett JE, et al. Mandell, Douglas, Bennett, and Dolin Principles and Practice of Infectious Disease. 5th ed. USA: Churchill Livingstone; 2000.

5. Vaughan DG, Asharg T, Riardan EP. General Ophthalmology. 5th ed. USA: Appleton and Lange; 1999.

6. Grammer J, Erb C, Kamin G, et al. Ophthalmomyiasis externa due to the sheep botfly Oestrus ovis in South-West Germany. Gev J Ophthalmol. 1995;4(3):188-195.

7. Sucilathangam G, Meenakshisundaram A, Hariramasubramanian S, et al. External Ophthalmomyiasis which was caused by sheep Botfly (Oestrus Ovis) larvae: A report of ten cases. Journal of Clinical and Diagnostic Research. 2013;7(3):539-542.

8. Victor R, Bhargva K. Ophthalmomyiasis in Oman: a case report and comments. Wilderness Environ Med. 1998;9(1):32-35.

9. Maretic Z, Nadenic LA, Ladavic J, et al. Ophthalmomyiasis due to Oestrus ovis. Acta Trop. 1973;30(4):369-372.

10. Khurana S, Biswal M, Bhatti HS, et al. Ophthalmomyiasis: Three cases from North India. Indian J Med Microbiol. 2010;28(3):257-261.

11. Pandey A, Madan M, Asthana AK, et al. External ophthalmomyiasis caused by Oestrus ovis: a rare case report from India. Korean J Parasitol. 2009;47(1):57-59. 